\title{
Studies on Ram Acrosin
}

\section{FLUORIMETRIC TITRATION OF OPERATIONAL MOLARITY WITH 4-METHYLUMBELLIFERYL $p$-GUANIDINOBENZOATE}

\author{
By COLIN R. BROWN, ZARINA ANDANI* AND EDWARD F. HARTREE \\ Agricultural Research Council Unit of Reproductive Physiology and Biochemistry, \\ Cambridge CB3 0JQ, U.K.†
}

(Received 31 December 1974)

\begin{abstract}
1. Titration in sodium barbiturate buffer of acrosin, a serine proteinase from sperm acrosomes, with the ester substrate 4-methylumbelliferyl $p$-guanidinobenzoate gave rise to an incomplete 'burst' of 4-methylumbelliferone. Studies of the effects on the reaction of activators of acrosin $\left(\mathrm{Ca}^{2+}\right.$, water-miscible solvents) showed that titrations carried out in barbiturate buffer containing $1 \mathrm{M}-\mathrm{CaCl}_{2}$ and diluted with $0.2 \mathrm{vol}$. of dimethyl sulphoxide produced a rapid quantitative burst within $4 \mathrm{~min}$ at $20^{\circ} \mathrm{C}$. 2 . The net post-burst production of 4-methylumbelliferone was negligible because (a) the acyl-enzyme was very stable, and (b) the slow post-burst formation of 4-methylumbelliferone (turnover of acyl-enzyme) was virtually equal to the slow photolytic destruction of 4-methylumbelliferone that was liberated during the burst. 3 . The standard procedure permits titrations of $20-100 \mathrm{pmol}$ of acrosin, i.e. amounts normally taken for conventional rate assays, and with these amounts the impurities present in crude enzyme fractions did not interfere. The burst was judged to be quantitative on the basis of comparisons with titrations of acrosin with $p$-nitrophenyl $p^{\prime}$-guanidinobenzoate. 4 . The burst reaction of trypsin with the 4-methylumbelliferyl ester was inhibited by high $\mathrm{Ca}^{2+}$ concentrations and by dimethyl sulphoxide. 5 . The association and dissociation of complexes of both acrosin and trypsin with protein-type inhibitors (Kunitz pancreatic trypsin inhibitor and a spermatozoal acrosin inhibitor) are rather slow. It is thus possible, in certain cases, to use the ester to titrate both total enzyme in an inhibitor-enzyme mixture and net enzyme, i.e. the stoicheiometric excess of enzyme over inhibitor.
\end{abstract}

Jameson et al. (1973) have described active-site titrations of the serine proteinases $\alpha$ - and $\beta$ trypsins, thrombin and factor $\mathrm{Xa}$ with the ester substrate 4-methylumbelliferyl $p$-guanidinobenzoate (I). Acyl-enzyme intermediates were sufficiently stable to allow initial 'bursts' of 4-methylumbelliferone (II) to serve as measures of the operational molarities of the enzyme solutions. The advantage of this procedure is that, with fluorimetric determination of compound II, the titration can be at least 100 times more sensitive than customary spectrophotometric methods, e.g., with $p$-nitrophenyl $p^{\prime}$-guanidinobenzoate (Chase \& Shaw, 1970). Activesite titrations have hitherto been carried out mainly with extensively purified enzymes (Bender et al., 1966; Jameson et al., 1973; also references quoted in the latter paper). This is often obligatory for spectrophotometric methods, where accuracy calls

* Now Mrs. Z. Madden, Immunology Division, Addenbrooke's Hospital, Cambridge CB2 2QQ, U.K.

† Mailing address: Animal Research Station, 307 Huntingdon Road, Cambridge CB3 0JQ, U.K. for active-site concentrations of 5-10 $\mu \mathrm{M}$. Extraneous protein (and other contaminants) of non-purified enzymes can interfere with the spectrophotometric assay of $p$-nitrophenol, e.g. through co-precipitation. The much lower concentration of proteinase required for fluorimetric assay decreases the risk of interference in addition to conserving stocks of scarce materials. It therefore seemed to us that direct fluorimetric measurements of enzyme concentration could well replace customary assays, based on rates of substrate hydrolysis, at most if not all stages of purification of a serine proteinase.

We made the assumption that accurate active-site titrations are most likely to be achieved in conditions favouring a rapid reaction of proteinase with titrant. Making use of our experience with activators of acrosin (Brown et al., 1975) we have developed a fluorimetric procedure for assaying the molarity of ram acrosin solutions with compound I, a procedure that is applicable to crude enzyme fractions. The experiments in this paper support the view that the mechanism of the acrosin-compound I reaction 
may be represented in the same way as the general scheme for trypsin:

$$
\mathrm{E}+\mathrm{S} \stackrel{K_{1}}{\rightleftharpoons} \mathrm{ES} \stackrel{k_{2}}{\rightarrow} \mathrm{ES}^{\prime} \stackrel{k_{2}}{\rightarrow} \mathrm{E}+\mathrm{P}_{2}
$$

where $E S^{\prime}$ is the acyl-enzyme and $P_{1}$ is compound II.

\section{Materials}

Sucrose, analytical-grade, was from Fison's Scientific Ltd., Loughborough, Leics., U.K.; compound II was an Eastman product, m.p. $188-189^{\circ} \mathrm{C}$, supplied by Kodak Ltd., Kirkby, Liverpool, U.K. Crystalline bovine trypsin, Trasylol (Kunitz bovine basic pancreatic trypsin inhibitor), acrosomal inhibitor (an inhibitor of acrosin and trypsin that was isolated from ram spermatozoa) and dimethyl sulphoxide were as described in Brown et al. (1975). $p$-Nitrophenyl $p^{\prime}$-guanidinobenzoate hydrochloride was a gift from Dr. E. Shaw (Brookhaven National Laboratories, Upton, N.Y., U.S.A.).

The hydrochloride of compound I was prepared by condensing $p$-guanidinobenzoic acid hydrochloride (Chase \& Shaw, 1970) with compound II as described by Jameson et al. (1973), but with changes in the purification procedure. It was crystallized twice from acetic acid (crop 1, yield $65 \%$ ). The product was not obviously crystalline. Attempts to crystallize crop 1 from 2-methylbutan-2-ol-diethyl ether (Jameson et al., 1973) were unsuccessful. Part of crop 1 was dissolved in hot cyclohexanone, diluted with an equal volume of hot ethanol, and filtered. The solution was stored at room temperature as a $2-3 \mathrm{~cm}$ layer in an open flask for 4 days. White needles (crop 2) were deposited. Both crops were dried to constant weight in vacuo over $\mathrm{P}_{2} \mathrm{O}_{5}$. Crop 1 had m.p. $180-185^{\circ} \mathrm{C}$ (Found: C, 56.35; H, 4.50; N, 11.02; Cl, 9.16. $\mathrm{C}_{18} \mathrm{H}_{16} \mathrm{~N}_{3} \mathrm{ClO}_{4}, \frac{1}{2} \mathrm{H}_{2} \mathrm{O}$ requires $\mathrm{C}, 56.47 ; \mathrm{H}, 4.32$; $\mathrm{N}, 10.98 ; \mathrm{Cl}, 9.27 \%$ ). Crop 2 had m.p. $209-212^{\circ} \mathrm{C}$ (Found: $\mathrm{C}, 58.00 ; \mathrm{H}, 4.37 ; \mathrm{N}, 11.36 ; \mathrm{Cl}, 9.32$. $\mathrm{C}_{18} \mathrm{H}_{16} \mathrm{~N}_{3} \mathrm{ClO}_{4}$ requires $\mathrm{C}, 57.83 ; \mathrm{H}, 4.32 ; \mathrm{N}, 11.24$; $\mathrm{Cl}, 9.48 \%$ ). Jameson et al. (1973) give m.p. $219-221^{\circ} \mathrm{C}$ for a monohydrate.

\section{Ram acrosin}

Three preparations were used: fraction $\mathrm{S} 1 / 2$, a crude acid extract (pH 2.7) of 'denuded' spermatozoa; fraction FD, a freeze-dried product representing a partial purification of fraction S1/2; and an inhibitorfree freeze-dried product obtained from fraction FD by chromatography on a column of Sephadex G-75. For details see Brown et al. (1975). The freeze-dried enzyme preparations were used as $0.2 \%$ solutions in $1 \mathrm{~mm}-\mathrm{HCl}$. Unless otherwise stated experiments were carried out with the inhibitor-free preparation.

\section{Buffers}

Compound I, like p-nitrophenyl $p^{\prime}$-guanidinobenzoate, is more stable in barbiturate buffers than in Tris buffers. Titrations of acrosin (and trypsin) with compound I were followed in $0.1 \mathrm{M}$-sodium barbiturate- $\mathrm{HCl}$ buffers, $\mathrm{pH} 8.2$, containing $0-1.43 \mathrm{M}-$ $\mathrm{CaCl}_{2}$. In work with acrosin these buffers were usually diluted with $0.2 \mathrm{vol}$. of dimethyl sulphoxide. If $\mathrm{CaCl}_{2}$ exceeds $0.2 \mathrm{M}$ the addition of the solvent is obligatory, otherwise barbiturate crystallizes. Buffers containing dimethyl sulphoxide were stored at $5^{\circ} \mathrm{C}$ : after several weeks on the laboratory bench they become inhibitory towards the reaction of acrosin with compound I. The term 'standard buffer' will be used for $0.1 \mathrm{M}$-barbiturate-1.0 $\mathrm{M}-\mathrm{CaCl}_{2}, \mathrm{pH} 8.2$, diluted with $0.2 \mathrm{vol}$. of dimethyl sulphoxide.

\section{Titration reagents}

Standard ( $5 \mathrm{~mm}$ ) solutions of compounds I and II were prepared in $N$-methylpyrrolid-2-one (Jameson et al., 1973). They were stable for 6 months at $-20^{\circ} \mathrm{C}$. Appropriate dilutions were made daily in $1 \mathrm{~mm}-\mathrm{HCl}$ and stored below $20^{\circ} \mathrm{C}$. Hydrolysis of compound I occurs at a significant rate at higher temperatures.

\section{Methods}

\section{Determinations of operational molarities of acrosin (and trypsin)}

The method of Chase \& Shaw (1970) for titrating trypsin with $p$-nitrophenyl $p^{\prime}$-guanidinobenzoate was used by Schiessler et al. (1972) for titrating boar acrosin. We have used the same method for ram acrosin except that $0.2 \mathrm{M}-\mathrm{CaCl}_{2}$ was present and the substrate solution was made up as described by Jameson et al. (1973).

Fluorescence of compound II was measured at $20 \pm 0.5^{\circ} \mathrm{C}$ in an Aminco-Bowman ratio-recording spectrophotofluorimeter with wavelength settings $363 \mathrm{~nm}$ (excitation) and $457 \mathrm{~nm}$ (emission). Entrance and exit slits were 2 and $4 \mathrm{~mm}$ respectively.

Fluorimetric procedure. To assay $10-100 \mathrm{pmol}$ of acrosin (or trypsin) photometric sensitivity is adjusted so that fluorescence of $50 \mathrm{nM}$-compound II [in sodium barbiturate buffer-dimethyl sulphoxide $(5: 1, v / v)]$ in a standard cuvette $(10 \mathrm{~mm} \times 10 \mathrm{~mm})$ gives rise to about $40 \%$ of full-scale deflexion on an external recorder set at $20 \mathrm{mV}$. A cuvette containing $1 \mathrm{ml}$ of buffer is placed in the fluorimeter and the pen is brought to the left side of the recorder chart which is running at $1 \mathrm{~cm} / \mathrm{min}$. (Appropriate buffers are described in the Results section.) The cuvette next receives $5 \mu \mathrm{l}$ of $0.1 \mathrm{~mm}$-compound I $(500 \mathrm{pmol})$ : this should give rise to a deflexion of not more than $2 \%$ of full scale. The enzyme solution (up to $10 \mu \mathrm{l}$ ) is then added. The initial burst of compound II and any subsequent slow production of compound II 
are followed for $4-10 \mathrm{~min}$. After $10 \mathrm{~min}$, or earlier if the pen becomes stationary, the pen is backed off (if necessary) to the left half of the chart and, 10s later, $5 \mu \mathrm{l}$ of $0.01 \mathrm{~mm}$-compound II is added to obtain a standard deflexion for $50 \mathrm{pmol}$ of compound II. The sensitivity of the assay can be increased at least fivefold, without increase in instrumental 'noise', by the use of Aminco-Bowman micro-cuvettes (diameter $3 \mathrm{~mm}$ ). The two crops of compound I gave identical results.

For certain types of experiment it was necessary to initiate the burst by added compound $I$ to buffered acrosin. These were: (a) experiments on the effects of inhibitors, where a prior $5 \mathrm{~min}$ contact of enzyme and inhibitor at $\mathrm{pH}$ about 8 was necessary; $(b)$ titrations of acrosin fraction $\mathrm{S} 1 / 2$, sincesuch fractions developed fluorescence (equivalent to $2-4 \mathrm{pmol}$ of compound II) when added to barbiturate buffers.

\section{Results}

Exploratory experiments: influence of $\mathrm{Ca}^{2+}$, organic solvents and sucrose on the reaction of acrosin with compound I

Except where otherwise stated the experiments in this section were carried out with a single preparation of acrosin fraction FD.

Addition of $10 \mu \mathrm{g}$ of acrosin to $1 \mathrm{ml}$ of $0.1 \mathrm{M}$ sodium barbiturate buffer containing $500 \mathrm{pmol}$ of compound I gave rise to an immediate 'burst' of compound II, followed by slow production of compound II, presumably owing to turnover of the acylenzyme. The turnover phase was not linear but progressed at a decreasing rate for $20 \mathrm{~min}$ : thus extrapolation to zero time was impossible. The velocity of the burst reaction increased considerably in the presence of $\mathrm{CaCl}_{2}$ at concentrations up to $0.2 \mathrm{M}$. With $\mathrm{Ca}^{2+}$ present the turnover phase was not linear at first, but after $8 \mathrm{~min}$ the rate of formation of compound II was very low and virtually constant. Several water-soluble organic solvents activate trypsin (Castañeda-Agulló \& del Castillo, 1959) and the same solvents also activate acrosin in rate assays with synthetic substrates (Brown et al., 1975). Inclusion of 2-methylpropan-2-ol or dimethyl sulphoxide $(20 \%, v / v)$ in the barbiturate buffer increased the burst velocity of the reaction and after $6 \mathrm{~min}$ the turnover phase was slow and linear.

Acrosin fraction S1/2, a low-pH extract of spermatozoa, becomes cloudy at $\mathrm{pH} 8$ and the enzyme precipitates (Brown et al., 1975). Attempts to titrate fractions $S 1 / 2$ with compound $I$ in barbiturate buffers containing $0.2 \mathrm{M}-\mathrm{CaCl}_{2}, 2$-methylpropan-2-ol, or both were unsuccessful owing to progressive increase in opalescence. However, the presence of both dimethyl sulphoxide and $\mathrm{CaCl}_{2}$ (Table 1) prevented loss of transparency and permitted titrations of S1/2 fractions. An incidental advantage of
Table 1. Fluorescence at $20^{\circ} \mathrm{C}$ of $50 \mathrm{nM}$-compound II in buffers based on $0.1 \mathrm{M}$-sodium barbiturate, $\mathrm{pH} 8.2$

See under 'Exploratory experiments' in the Results section.

\section{Additions to buffer}

Fluorescence

(1) $0.2 \mathrm{M}-\mathrm{CaCl}_{2}$

(2) 0.2 vol. of $\mathrm{Me}_{2} \mathrm{SO}$ relative to (1)

(3) $0.2 \mathrm{M}-\mathrm{CaCl}_{2}-0.1 \mathrm{M}$-sucrose

[100]

(4) $0.2 \mathrm{M}-\mathrm{CaCl}_{2}-0.2$ vol. of $\mathrm{Me}_{2} \mathrm{SO}$

111

110

124

Table 2. Release of compound II from compound I by an acrosin fraction FD: effect of adding dimethyl sulphoxide to the buffer medium (0.1 M-barbiturate- $\left.0.2 \mathrm{M}-\mathrm{CaCl}_{2}\right)$

Reactions were carried out in $1.0 \mathrm{ml}$ of buffer or of bufferdimethyl sulphoxide. The burst was determined by extrapolation to zero time of the linear rate after $8 \mathrm{~min}$ (see the text).
Volume of $\mathrm{Me}_{2} \mathrm{SO}$ added to 1 vol. of buffer

$0^{*}$
0.04
0.08
0.15
$0.20^{*}$
0.25
0.30

Burst produced by $10 \mu \mathrm{g}$ of acrosin (pmol)

45.1

48.5

47.8

$48.7 \dagger$

$49.4 \dagger$

43.2

40.0
* Buffers 1 and 4 of Table 1.

$\dagger$ Increase in concentration of compound II ceases after $4 \mathrm{~min}$.

this solvent is that it enhances the fluorescence of compound II.

Further experiments (Table 2) revealed an optimum value (in terms of the magnitude of the burst) for the ratio dimethyl sulphoxide/buffer. Further, when the ratio was $0.15-0.20$ the post-burst formation of compound II was negligible. The essential points from these experiments are illustrated in Fig. 1. Buffer 4 gave rise to a higher burst than did the others if extrapolation was carried out. We accept buffer 4 values for the burst as being the most accurate since they agreed within $5 \%$ with titrations performed with $p$-nitrophenyl $p^{\prime}$-guanidinobenzoate. To compare the two methods we used $0.8-1.6 \mathrm{mg}$ of acrosin with the $p$-nitrophenyl ester and 5-10 $\mu \mathrm{g}$ of acrosin with compound I.

Since we had planned to study the effects of Trasylol on the reaction of compound I with acrosin, and since solutions of Trasylol in $0.25 \mathrm{M}$-sucrose had been prepared for other experiments, we studied the effect of sucrose on the titration with compound I. As Fig. 1 shows, sucrose causes a considerable 


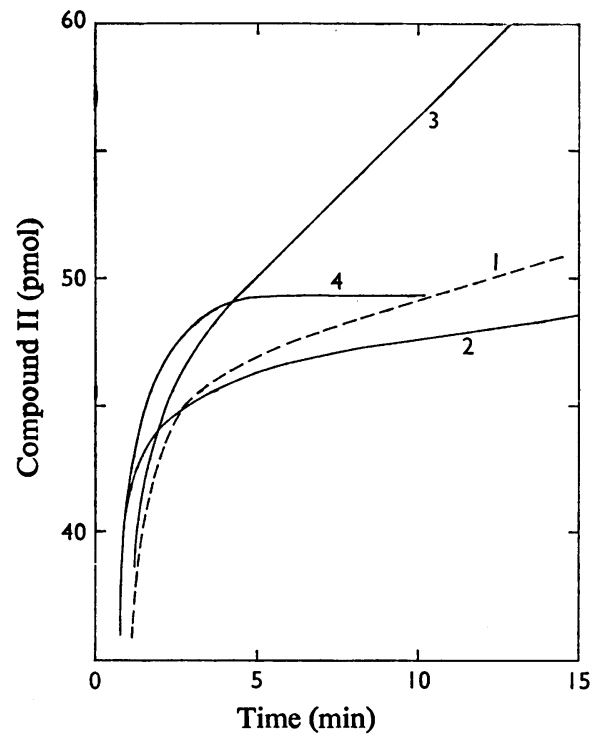

Fig. 1. Fluorimetric titration of acrosin fraction FD with compound I: time-course of release of compound II after addition of $10 \mu \mathrm{g}$ of acrosin to $500 \mathrm{pmol}$ of compound I in $1 \mathrm{ml}$ of buffer

Curves are numbered to correspond with buffers in Table 1.

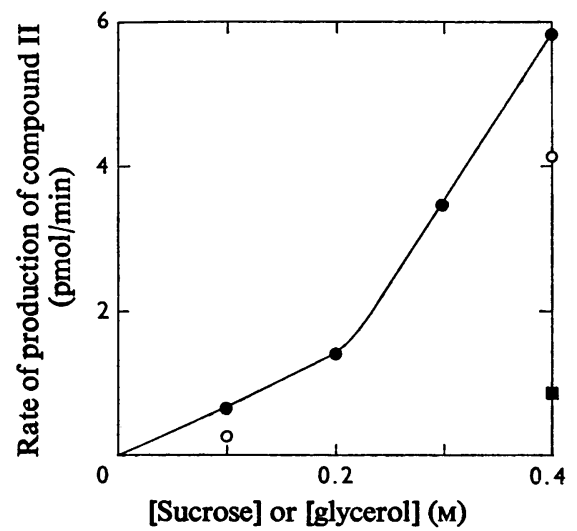

Fig. 2. Production of compound II from compound $I$ in buffers containing $0.2 \mathrm{M}-\mathrm{CaCl}_{2}$ and sucrose or glycerol

- Post-burst rates, as a function of sucrose concentration, in experiments as Fig. 1, Expt. 3; $\bigcirc$, rates in controls without enzyme; $\square$, post-burst rate in the presence of glycerol.

increase in the post-burst hydrolysis of compound $I$. Incorporation of sucrose at concentrations up to $0.4 \mathrm{M}$ gave rise to still greater post-burst rates (Fig. 2). Controls without enzyme also exhibited hydrolysis rates that increased with sucrose concentration. Thus rates shown by the curve of Fig. 2 arise mainly from an acrosin-independent, but sucrose-dependent, hydrolysis. Glycerol had a significant but much smaller catalytic power. The sucrose effect appears to be intrinsic and not due to contaminating esterase activity. Buffers $\left(0.1 \mathrm{M}\right.$-barbiturate $\left.-0.2 \mathrm{M}-\mathrm{CaCl}_{2}\right)$ were made up containing $0.4 \mathrm{M}$-sucrose from various sources [cane sugar (Tate and Lyle Ltd., Mincing Lane, London E.C.3, U.K.), beet sugar (British Sugar Corp., Tower Hill, London E.C.3, U.K.) and a highly purified sucrose (Aristar, BDH Chemicals, Poole, Dorset, U.K.)]. In addition, the different sucroses were autoclaved, as $1 \mathrm{M}$-solutions, for $2 \mathrm{~h}$ at $120^{\circ} \mathrm{C}$ and incorporated at $0.4 \mathrm{M}$ in barbiturate- $-\mathrm{CaCl}_{2}$ buffer. The rates of hydrolysis of $500 \mathrm{pmol}$ of compound I in $1 \mathrm{ml}$ of each of these buffers agreed within $6 \%$ of the mean value $(4.0 \mathrm{pmol} / \mathrm{min})$.

The negligible post-burst turnover in barbiturate$0.2 \mathrm{M}-\mathrm{CaCl}_{2}$-dimethyl sulphoxide buffer suggested that it might be the ideal medium for titration of acrosin. However, later experiments showed that with all samples of inhibitor-free acrosin, and even with some samples of acrosin fraction FD, a quite high post-burst turnover occurred in this buffer.

Influence of $\mathrm{Ca}^{2+}$ concentration on the reactions of acrosin and trypsin with compound I

Acrosin. Fig. 3 shows the effects of up to $1.43 \mathrm{M}$ $\mathrm{CaCl}_{2}$ on the titration of acrosin in buffers containing dimethyl sulphoxide. Increasing $\mathbf{C a C l}_{2}$ concentrations suppressed the turnover, but concentrations above $1.2 \mathrm{M}$ inhibited the burst rate. All three types of ram acrosin were tested in standard buffer (i.e. with $1 \mathrm{M}-\mathrm{CaCl}_{2}$ present) and if the quantities of

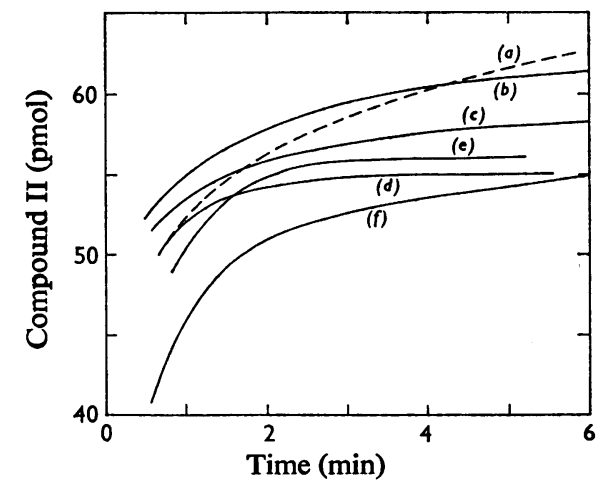

Fig. 3. Titration curves of $10 \mu \mathrm{g}$ of acrosin in bufferdimethyl sulphoxide $(5: 1, v / v)$

The buffer ( $0.1 \mathrm{M}$-barbiturate, $\mathrm{pH} 8.2)$ contained the following molarities of $\mathrm{CaCl}_{2}$ : (a) 0.20 ; (b) 0.57 ; (c) 0.75 ; (d) 0.98 ; (e) 1.20 ; (f) 1.43 . 
compound I and enzyme were 500 and $25-75$ pmol respectively the post-burst turnover was insignificant. Replacement of $\mathrm{CaCl}_{2}$ by $\mathrm{MgCl}_{2}$ led to essentially identical results. Comparisons of titrations of acrosin (a) with compound I in standard buffer, and (b) with $p$-nitrophenyl $p^{\prime}$-guanidinobenzoate in $0.1 \mathrm{M}$ barbiturate- $0.2 \mathrm{M}-\mathrm{CaCl}_{2}$ again gave good agreement, i.e. within $5 \%$.

Trypsin. Titrations in the buffers listed in Fig. 3 showed that the burst rate was progressively inhibited by $\mathrm{CaCl}_{2}$ concentrations above $0.2 \mathrm{M}$. Jameson et al. (1973) used a calcium-free barbiturate buffer for titrating trypsin. We found that addition of up to $0.2 \mathrm{M}-\mathrm{CaCl}_{2}$ made the burst more rapid and slightly decreased the post-burst turnover rate. We therefore use buffer 1 (Table 1) for routine assays of trypsin. Addition of dimethyl sulphoxide to such buffers inhibits the burst rate considerably.

Optimum conditions for fluorimetric assay of acrosin: relationship between burst and concentration of enzyme

Fig. 4 shows results from titrations, in $1 \mathrm{ml}$ of standard buffer containing $500 \mathrm{pmol}$ of compound $\mathrm{I}$, of 2-20 $\mu \mathrm{g}$ of acrosin. The experimental points (filled circles) are based on pen deflexions at $4 \mathrm{~min}$ after addition of enzyme. With enzyme/substrate ratios $\left([\mathrm{E}]_{0} /[\mathrm{S}]_{0}\right)$ between 0.05 and 0.15 , the pen became stationary after 3-3.5 min and $\pi$, the magnitude of the

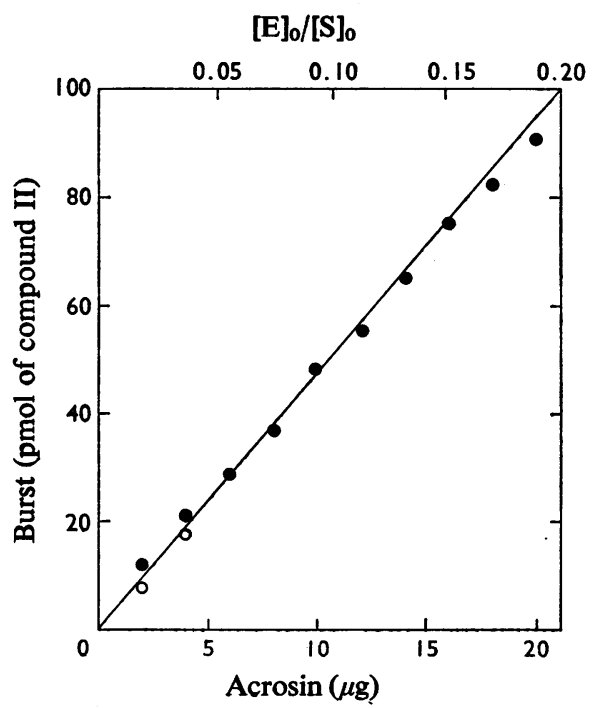

Fig. 4. Relationship of the burst to weight of acrosin

Assays were as in Fig. 3 but with standard buffer. O, Burst determined from recorder-pen deflexion $4 \mathrm{~min}$ after adding acrosin; $O$, burst calculated from extrapolation back to time of addition of acrosin (where this method gives a different burst value).
Table 3. Side reactions of compound I accompanying the formation of acyl-acrosin

Cuvettes received $1 \mathrm{ml}$ of standard buffer followed by additions shown below. (A) Controls without enzyme. (B) Titrations of acrosin at two temperatures; also controls without enzyme. Rates in (B) were measured with intermittent irradiation and with a 2.5 - fold increase in sensitivity (possible error: \pm 0.04 ).

Rate of production of compound II

\begin{tabular}{|c|c|c|c|c|c|}
\hline $\begin{array}{r}\text { Te } \\
\text { pers } \\
\left(^{\circ}\right.\end{array}$ & $\begin{array}{l}\text { m- } \\
\text { ture } \\
\text { C) }\end{array}$ & $\begin{array}{c}\text { Com- } \\
\text { pound } \\
\text { I } \\
\text { (pmol) }\end{array}$ & $\begin{array}{c}\text { Acrosin } \\
\text { (pmol) }\end{array}$ & $\begin{array}{l}\text { Before adding } \\
50 \mathrm{pmol} \text { of } \\
\text { compound II } \\
\text { (pmol/min) }\end{array}$ & $\begin{array}{l}\text { After adding } \\
50 \text { pmol of } \\
\text { compound II } \\
\text { (pmol } / \mathrm{min} \text { ) }\end{array}$ \\
\hline (A) & $\begin{array}{l}20 \\
20 \\
20 \\
20 \\
20\end{array}$ & $\begin{array}{r}500 \\
1000 \\
2000 \\
4000 \\
-\end{array}$ & - & $\begin{array}{l}0.4 \\
1.5 \\
4.1 \\
8.4\end{array}$ & $\begin{array}{r}-0.2 \\
0.6 \\
2.8 \\
6.9 \\
-0.4\end{array}$ \\
\hline (B) & $\begin{array}{l}20 \\
25 \\
20 \\
25\end{array}$ & $\begin{array}{l}500 \\
500 \\
500 \\
500\end{array}$ & $\begin{array}{l}52 \\
52 \\
- \\
-\end{array}$ & $\begin{array}{l}0.39^{*} \\
0.81^{*} \\
0.37 \\
0.51\end{array}$ & \\
\hline
\end{tabular}

burst (Bender et al., 1966), was linearly related to the weight of acrosin. When the ratio 0.15 was exceeded, $\pi$ reached a maximum at about $3 \mathrm{~min}$ and then decreased very slowly. This arises from photolytic breakdown of compound II (see below). Experiments in which $[\mathrm{E}]_{0} /[\mathrm{S}]_{0}$ exceeded 0.2 showed progressively increasing divergences from linearity owing to incomplete formation of ES. When the ratio was less than 0.05 the burst was followed by a slow turnover. Extrapolation to zero time in such cases gave $\pi$ values (open circles) which tended to lie closer to the linear relationship in Fig. 4. Provided that the ratio is of the order of 0.1 it is possible, by changing the concentration of compound I, to vary the sensitivity of the method to cover different acrosin ranges, e.g. 2.5-25, 25-250 pmol. Increasing the quantity of compound I above 1500 pmol leads to an inconveniently high rate of spontaneous hydrolysis (see below).

Side reactions accompanying and following the burst reaction

Photodecomposition of compound II during titrations of $\alpha$-trypsin with compound I was noted by Jameson et al. (1973), who eliminated it by irradiating the cuvette intermittently. We have titrated acrosin in standard buffer by such a method (1.5s irradiation at $0.5 \mathrm{~min}$ intervals) and have found that pre- and post-burst rates are almost identical. Further, back-extrapolation of the latter rates gave results that were not significantly different from 
results obtained with continuous irradiation, which eliminated net post-burst changes in the concentration of compound II.

The recorded post-burst rates in our experiments, after correction for spontaneous hydrolysis, should equal the rate of turnover of the acyl-enzyme less the rate of photolysis of compound II. Spontaneous hydrolysis was not markedly affected by the presence of $\mathrm{CaCl}_{2}$ or dimethyl sulphoxide. A study of this hydrolysis, as well as of post-burst changes (Table 3), revealed the following points.

(1) Rates of spontaneous hydrolysis of compound I increased with concentration (A). When a standard $50 \mathrm{pmol}$ of compound II was subsequently added the rates fell and even became negative (in terms of concentration of compound II). That photolysis of compound II occurs is confirmed by its slow disappearance from the control without compound I. No loss of compound II occurred when the same control was run with intermittent irradiation.

(2) Comparison of pre- and post-burst rates in acrosin titrations at $20^{\circ} \mathrm{C}$ and $25^{\circ} \mathrm{C}$ (B) were carried out with intermittent irradiation. The spontaneous (pre-burst) hydrolysis had a large temperature coefficient and the post-burst rate had a still larger one. A noteworthy finding was that at $20^{\circ} \mathrm{C}$ the pre- and post-burst rates of hydrolysis of compound I did not differ significantly $(0.37,0.39)$, i.e. the acyl-enzyme is very stable in standard buffer at this temperature. Further, in $1 \mathrm{ml}$ of standard buffer containing $450 \mathrm{pmol}$ of compound $I$ and $50 \mathrm{pmol}$ of compound II (conditions prevailing immediately after the burst promoted by $50 \mathrm{pmol}$ of acrosin) the rate of formation of compound II by spontaneous hydrolysis was almost cancelled out by the rate of photolysis of liberated compound II.

Effect of concentration of compound $I$ on $\pi$ at a constant acrosin concentration

On the basis of a kinetic analysis by Gutfreund \& Sturtevant (1956) of chymotrypsin catalysis, Bender et al. (1966) derived the equation:

$$
\pi=[\mathrm{E}]_{0}\left(\frac{k_{2}}{k_{2}+k_{3}}\right)^{2} /\left(1+\frac{K_{m}}{[\mathrm{~S}]_{0}}\right)^{2}
$$

A good enzyme titrant must satisfy the condition $k_{2} \gg k_{3}$ and $[\mathrm{S}]_{0} \gg K_{m}$, so that $\pi$ becomes equal to $[\mathrm{E}]_{0}$. The progress of fluorimetric titration indicates that the former condition holds for the reaction of acrosin with compound $I$ in standard buffer. Thus eqn. (2) may be simplified and rearranged to give eqn. (3)

$$
\frac{1}{\sqrt{\pi}}=\frac{1}{\sqrt{[\bar{E}]_{0}}}+\frac{K_{m}}{[\mathrm{~S}]_{0} \sqrt{[\bar{E}]_{0}}}
$$

from whichit follows (Bender et al., 1966) that a plot of $1 / \sqrt{\pi}$ against $1 /[\mathrm{S}]_{0}$ will intercept the ordinate at $1 / \sqrt{[\mathrm{E}}]_{0}$.

Data for such a plot were obtained by titrating $10 \mu \mathrm{g}$ of acrosin with various amounts of compound $I$.

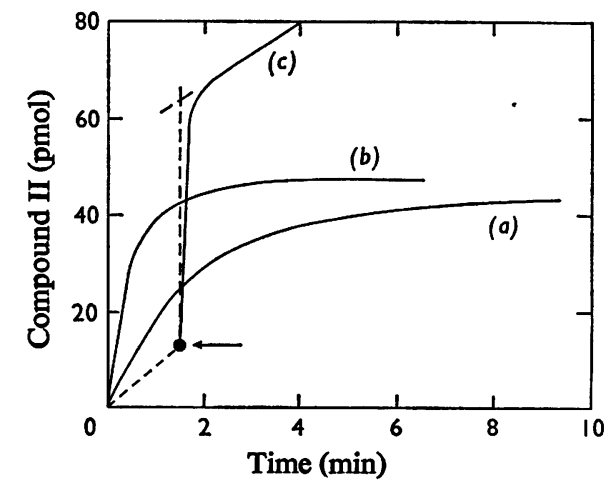

Fig. 5. Representative titrations in standard buffer of $10 \mu \mathrm{g}$ of acrosin with different quantities of compound $I$

(a) $150 \mathrm{pmol}$; (b) $500 \mathrm{pmol}$; (c) $4000 \mathrm{pmol}$. The three $\pi$ values, with others, are utilized in Fig. 6. ----, Spontaneous hydrolysis of compound I before addition of acrosin (arrow).

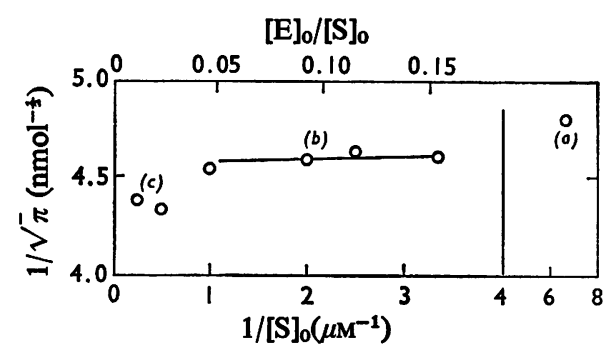

Fig. 6. Variation in $\pi$ with concentration of compound $I$ (plotted as described by Bender et al., 1966)

Points $(a),(b)$ and $(c)$ are derived from Fig. 5. Point $(b)$, representing standard conditions for titration, was used to calculate $[\mathrm{E}]_{0}$.

Some of the recorder traces are illustrated in Fig. 5. With $150 \mathrm{pmol}$ of compound I the burst was apparently incomplete within $10 \mathrm{~min}$ (curve $a$ ). With $300-500$ pmol a normal type of titration curve was obtained (e.g. curve b). With 1000 pmol the pre- and post-burst rates were significant and extrapolation was necessary for determining the burst. With still higher quantities of compound $I$ these rates were considerable, e.g. curve $c(4000 \mathrm{pmol})$. The plot of $1 / \sqrt{\pi}$ against $1 /[$ S ] o (Fig. 6) reveals virtually no change in $\pi$ over the middle section $\left([\mathrm{E}]_{0} /[\mathrm{S}]_{0}=0.05-0.15\right)$ where titration was complete within $4 \mathrm{~min}$. When pre- and post-burst rates are high and the burst rate very rapid $\left(1 /[S]_{0} \neq 0.5\right)$ manual addition of enzyme to the cuvette, and subsequent mixing, could not be 
timed as accurately as the assay demands. This difficulty, together with the fact that post-burst rates are somewhat lower than pre-burst rates, adds uncertainty to $\pi$ values. In such assays these values were consistently $5-10 \%$ greater than those obtained with lower concentrations of compound I. It may, however, be concluded that $[\mathrm{S}]_{0} \gg K_{m}$ in normal assay conditions and that extrapolation on the basis of Fig. 6 is unnecessary.

With provision of means for accurate timing of addition of acrosin, and simultaneous rapid mixing, Expt. $c$ (Fig. 5) could become the basis of a very rapid fluorimetric titration.

\section{Fluorimetric titration of acrosin and trypsin in the} presence of inhibitors

Acrosin-acrosomal inhibitor. The two upper curves of Fig. 7 illustrate the influence of up to $30 \mu \mathrm{g}$ of acrosomal inhibitor on the titration of $42 \mathrm{pmol}$ of acrosin and the effect of briefly storing enzyme and inhibitor together, in standard buffer, before adding compound I. Curve $a$, taken from Brown et al. (1975), is a determination of the stoicheiometric relationship of the acrosin and inhibitor preparations by extrapolation of the linear portion of the curve. Thus by the fluorimetric method acrosin may be assayed in the presence of a considerable molar excess of inhibitor. This could be of practical value in view of the widespread occurrence of the acrosomal inhibitor in spermatozoa.

Trypsin-Trasylol and acrosin-Trasylol. Trypsin associates stoicheiometrically $(1: 1)$ with Trasylol, and the equilibrium constant is so low $\left(6 \times 10^{-14} \mathrm{M}\right)$ that complete inhibition of the hydrolysis of $p$-tosyl-

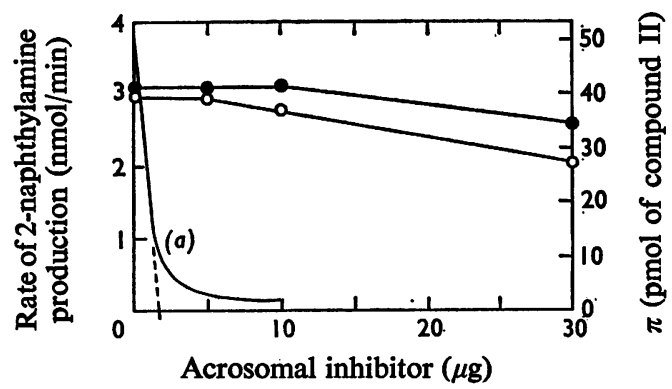

Fig. 7. Fluorimetric titrations of acrosin in the presence of different amounts of acrosomal inhibitor

, Burst was initiated by adding $8 \mu$ g of enzyme to standard buffer containing inhibitor and substrate $(500 \mathrm{pmol}$ of compound I). $\bigcirc$, Buffer+enzyme+inhibitor was stored for $5 \mathrm{~min}$ and the burst was initiated by adding substrate. (a) Curve from Fig. 9 of Brown et al. (1975): hydrolysis of $N$ - $\alpha$-benzoyl-DL- arginine 2-naphthylamide by mixtures of different amounts of inhibitor with $8 \mu \mathrm{g}$ of the acrosin preparation used for the fluorimetric titrations.

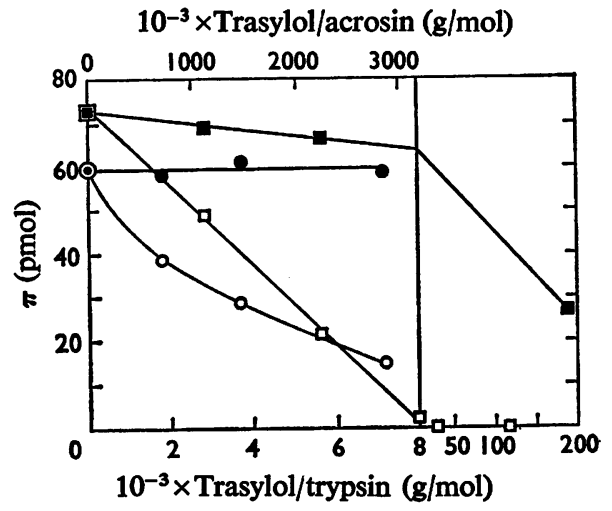

Fig. 8. Fluorimetric titrations of trypsin and acrosin in the presence of Trasylol

Trypsin (73pmol) was titrated in $0.1 \mathrm{M}$-barbiturate$0.2 \mathrm{M}-\mathrm{CaCl}_{2}$; acrosin $(59 \mathrm{pmol})$ was titrated in standard buffer. $\square$, Trypsin, Trasylol and buffer were mixed and $500 \mathrm{pmol}$ of compound I was added $5 \mathrm{~min}$ later; $\mathrm{a}$, trypsin was added to a mixture of buffer, Trasylol and compound I. $O$, As $\square$ but with acrosin; $\bullet$, as $\square$ but with acrosin.

L-arginine methyl ester has been observed in equimolar $(0.4 \mu \mathrm{M})$ mixtures of enzyme and inhibitor (Vincent \& Lazdunski, 1972). We have obtained a comparable result by fluorimetric assay of residual (uninhibited) enzyme in trypsin-Trasylol mixtures, provided that enzyme $(0.073 \mu \mathrm{M})$ and inhibitor were mixed, in appropriate buffer, $5 \mathrm{~min}$ before addition of compound I (Fig. 8, open squares). The molecular weight of Trasylol is 6513 (Kassell et al., 1963), but the equivalence point in Fig. 8 is $8000 \mathrm{~g} / \mathrm{mol}$ of trypsin. We thus assume the Trasylol preparation to be $84 \%$ pure. When trypsin was added to buffer containing compound I and Trasylol very little inhibition occurred unless the inhibitor was present in large excess (Fig. 8, closed squares). Similar experiments with acrosin-Trasylol mixtures (Fig. 8) showed that, with enzyme added last, $\pi$ remained constant while the molar ratio Trasylol/acrosin varied between 0 and 360. However, with prior contact of enzyme and inhibitor, association occurred (Fig. 8, open circles), the equilibrium constant being approx. $10^{-5} \mathrm{M}$. If the $\mathrm{pH}$ was 2-3 during prior contact of either trypsin or acrosin with Trasylol, and release of compound II was initiated by adding the enzyme-inhibitor mixture to buffered compound $I, \pi$ values were not significantly different from those obtained when either of the enzymes was added to buffer containing compound I and Trasylol.

\section{Discussion}

Bender et al. (1966) have considered the inherent difficulties in conversion of the velocity of an enzymecatalysed reaction into a chemically rigorous measure 
of quantity of enzyme present. Such calculations call for an absolute standard, namely a completely purified enzyme. This is, in practice, unattainable. Repeatedly crystallized enzymes, particularly proteinases, normally contain impurities and these usually include structurally or chemically modified enzyme. Reaction velocity is itself an uncertain measure of quantity of enzyme present. The ratio of activities of standard and 'unknown' enzyme samples may be influenced by several factors. These include: (1) presence of uncharacterized activators or inhibitors in non-purified enzymes and (2) choice of substrate concentration. For practical reasons the concentration may be below that required for nearsaturation conditions and routine determinations of $V_{\max }$ may be deemed too tedious. Further, values of $V_{\max }$ may be affected by activators and inhibitors. As we have shown elsewhere (Brown et al., 1975) the activity of acrosin may be stimulated by inorganic cations, and very low concentrations of an inhibitor present in spermatozoa can influence the effects of cations on acrosin considerably. Such factors tend to invalidate inter-laboratory comparisons. Similarly interspecies comparisons have uncertain value when based on a standardized rate-assay procedure: one that may evoke various degrees of activation among acrosin preparations from different sources.

Most of the above problems may be avoided, or minimized, by assays based on direct titration of active sites. If $[\mathrm{S}]_{0} \gg K_{m}$ and $\mathrm{ES}^{\prime}$ is stable, $\left[\mathrm{P}_{1}\right]$ is equal to $[E]_{0}$. The presence of enzyme inhibitors will increase $K_{m}$ (app.) and the ratio [S $]_{0} / K_{m}$ may no longer be high enough to ensure the equivalence of $\left[\mathrm{P}_{1}\right]$ and $[E]_{0}$. However, by making use of the sluggishness of the associations and dissociations of proteinaseinhibitor complexes we have been able to demonstrate the equivalence of acrosin and compound II in the presence of both acrosomal inhibitor and Trasylol and a near-equivalence of trypsin and compound II in the presence of Trasylol (Fig. 8).

A survey of published procedures for active-site titrations revealed that effects of variations in buffer composition, where these involve no change in $\mathrm{pH}$, appear not to have been investigated. There is no presumptive reason why a buffer that gives rise to maximum activity in an overall sequence (eqn. 1), i.e. in a rate assay, should also be most appropriate for the sequence $E+S \rightarrow E S^{\prime}$ involving a different substrate. A prime requirement for the latter reaction is the stability of $E S^{\prime}$, and in this respect the standard buffer containing $1 \mathrm{M}-\mathrm{CaCl}_{2}$ and dimethyl sulphoxide is superior to barbiturate and barbiturate- $-\mathrm{CaCl}_{2}$ for titration of acrosin with compound I. On the other hand, when the acrosin-catalysed hydrolysis of $N$ - $\alpha$-benzoyl-L-arginine ethyl ester (Brown et al., 1975) was measured in a series of dimethyl sulphoxide-containing buffers of the type specified in Fig. 3, activity reached a maximum with
$0.3 \mathrm{M}-\mathrm{CaCl}_{2}$ and decreased with further rise in $\mathrm{CaCl}_{2}$ concentration.

Jameson et al. (1973) found that at $25^{\circ} \mathrm{C}$ the burst reaction with $\alpha$-trypsin and compound I required more than $10 \mathrm{~min}$ for completion, whereas with $\beta$ trypsin it was complete within the time taken to mix the reagents $(5 \mathrm{~s})$. We have evidence that the inhibitor-free acrosin consists of more than one active species (Brown et al., 1975), but the time-scale of our titrations rules out the detection of enzyme components with reaction rates comparable with that of $\beta$ trypsin.

By an empirical approach we arrived at a fluorimetric titration procedure with three advantages, namely, the burst is rapid, the acyl-enzyme is stabilized, and the post-burst breakdown of compound I is effectively equivalent to the photodecomposition of liberated compound II. This balance depends not only on the buffer composition, and to some extent on $[\mathrm{E}]_{0} /[\mathrm{S}]_{0}$, but also on the intensity of the exciting radiation. One must not therefore assume that with a different instrument a zero post-rate will automatically be obtained in the conditions that we describe. However, with a stabilized acyl enzyme, post-burst rates will be slow enough for reliable extrapolations if instrumental and procedural adjustments fail to produce a negligible net rate of formation of compound II after the burst is complete.

In the wider context of the development of new procedures for titrating hydrolytic enzymes our experience suggests that study of the influences of temperature and of buffer composition (including the addition of activators) may prove fruitful.

We thank Dr. E. Shaw for the gift of p-nitrophenyl $p^{\prime}$-guanidinobenzoate hydrochloride.

\section{References}

Bender, M. L., Begué-Cantón, M. L., Blakeley, R. L., Brubacher, L. J., Feder, J., Gunter, C. R., Kézdy, F. J., Killheffer, J. V., Marshall, T. H., Miller, C. G., Roeske, R. W. \& Stoops, J. K. (1966) J. Am. Chem. Soc. 88, 5890-5913

Brown, C. R., Andani, Z. \& Hartree, E. F. (1975) Biochem. J. 149, 133-146

Castañeda-Agulló, M. \& del Castillo, L. M. (1959) J. Gen. Physiol. 42, 617-633

Chase, T. \& Shaw, E. (1970) Methods Enzymol. 19, 20-27

Gutfreund, H. \& Sturtevant, J. M. (1956) Biochem. J. 63, 656-661

Jameson, G. W., Roberts, D. V., Adams, R. W., Kyle, W. S. A. \& Elmore, D. T. (1973) Biochem. J. 131, 107-117

Kassell, B., Radicevic, M., Berlow, S., Peanasky, P. J. \& Laskowski, M. (1963)J. Biol. Chem. 238, 3274-3279

Schiessler, H., Fritz, H., Arnhold, M., Fink, E. \& Tschesche, H. (1972) Hoppe-Seyler's Z. Physiol. Chem. 353, 1638-1645

Vincent, J. P. \& Lazdunski, M. (1972) Biochemistry 11, 2967-2977 